University of Montana

ScholarWorks at University of Montana

Spring 2013

\title{
John Evelyn: The Forestry of Imagination
}

James C. McKusick

University of Montana - Missoula, mckusickj@umkc.edu

Follow this and additional works at: https://scholarworks.umt.edu/eng_pubs

Part of the English Language and Literature Commons Let us know how access to this document benefits you.

\section{Recommended Citation}

McKusick, James C., "John Evelyn: The Forestry of Imagination" (2013). English Faculty Publications. 17. https://scholarworks.umt.edu/eng_pubs/17

This Article is brought to you for free and open access by the English at ScholarWorks at University of Montana. It has been accepted for inclusion in English Faculty Publications by an authorized administrator of ScholarWorks at University of Montana. For more information, please contact scholarworks@mso.umt.edu. 
${ }^{7}$ Compared to the wild goings-on in the New York, the music scene in Boston seems a model of propriety. On it, see Broyles's earlier "Music of the Highest Class," Elitism and Popnulism in Antebellum Boslon (Yale UP, 1988).

${ }^{8}$ Nevins \& Thomas 4: 61, 524. Beethoven's symphonies struggled to make their way not only in the United States but also in Germany and Austria, where audiences found the Erovica "horribly long" (entselzlich ling) (Martin Geck, Peter Schleuning, "Geschrieben auf Bonaparte." Beethovens "Eroica" Revolution, Resktion, Rezeption, [Reinbek bei Hamburg: Rowohlt, 1989], 203).

${ }^{9}$ Three-quarters of an hour for the Fifth Symphony would now be considered unusually slow. For a sampling of the reception of Beethoven's music by New York's concertgoers, see (Lawrence 1: 110; 2: 709; 3: 317-18, 430-31).

${ }^{10}$ In later life, as performances became more frequent, Strong responded strongly to the demanding Ninth. Since it required in addition to a large orchestra, the additional expense of a chorus and trained soloists, it was rarely performed in America until well into the century. And its length tested American audiences.

1 Such attitudes persisted. In 1891, after a similar painting by Vanderlyn, his Arialne Asleep on the Island of Naxos, had entered the collection of the Pennsylvania Academy, its "flagrant indelicacy" made several women so uncomfortable they asked to have it removed from public view (16).
${ }^{12}$ And so it went for decades, up to and well beyond Harriet Beecher Stowe's attacks on Byron for his behavior in relation to his wife. In her 1869 article in the Allantic Monthly she defended the conduct of Lady Byron, who had died in 1860, against allegations of coldness and rigidity that Byron's friends had made regarding her. In 1870, she returned to the attack in a book, Lady Byron Vindicated. A History of the Byron Controversy. Both publications, by asserting that Byron had ill-treated his wife, started rumors and allegations that further damaged Byron's American reputation. Stowe's attacks launched a major controversy that festered for years, in Britain as well as in America, where Anthony Trollope's brilliant indictment in The Eustace Diamonds (1873) of Lizzie Eustace's values through her fascination with Byron's "Corsair" image kept the pot simmering throughout the decade.

\section{WORKS CITED}

Clubbe, John. Byron, Sully, and the Power of Portraiture.: Ashgate, 2005; Lawrence, Vera Brodsky Strong on Music. The New York Music Scene in the Days of George Templeton Strong, 1836-1875. 3 vols. Oxford UP, 1988, U of Chicago P, 1995, 1999; Levine, Lawrence W. 19th-Century Music (13.3) 1990: 261-67; Starr, S. Frederick, Bamboula! The Life and Times of Louis Moreau Gottschalk. Oxford UP, 1995; Nevins, Allan and Halsey Thomas ed. The Diary of George Templeton Strong. 4 vols. Macmillan, 1952; Saloman, Ora Frishberg. Beethoven's Symphonies and J. S. Dwight. Northeastern UP, 1995.

\section{John Evelyn: The Forestry of Imagination

\author{
James C. McKusick \\ University of Montana
}

John Evelyn (1620-1706) was the son of a wealthy landowner in the county of Surrey, England. He was educated at Balliol College, Oxford, and the Middle Temple, London. Starting at age ten, and continuing for the next fifty years, he kept a personal diary (Darley 8). First published in 1818, Evelyn's Diary provides a fascinating record of people, places, and events that he witnessed during a turbulent period of English history. Evelyn also published over thirty books on fine arts, forestry, numismatics, and religion.

In his political outlook, Evelyn was a staunch Royalist. However, he decided not to join the Royalist cause during the English Civil War, choosing instead to travel extensively through France and Italy. In 1647, during a sojourn in Paris, he married Mary Browne, the daughter of Sir Richard Browne, Charles I's ambassador to France. Evelyn returned to England in 1652, acquiring his father-in-law's estate at Sayes Court (on the Thames east of London), and settling into the life of a country gentleman. After the restoration of the monarchy in 1660 , Evelyn played a more active role in public affairs, serving on several royal commissions (Darley 192).

Evelyn was appointed as a founding member of the Royal Society in 1662, and in this capacity he published Sylva, or a Discourse of Forest-Trees, and the Propagation of Timber (1664). Evelyn's Sylva foreshadows the development of a conservationist ethic in the management of forests and wildlands throughout the English-speaking world. In this treatise, Evelyn advocates the replanting of woodlands that had been devastated during the English Civil War as a means of restoring the nation's defenses, particularly its navy and merchant marine. The book describes the various kinds of trees, their cultivation, and the best use for each kind of timber. Foremost among all English tree species is the oak, which Evelyn regards as producing the most elegant and useful of kind of wood, almost magical in its properties:

The land and the sea do sufficiently speak for the improvement of this excellent material; houses and ships, cities and 
navies are built with it; and there is a kind of [oak] so tough, and extreamly compact, that our sharpest tools will hardly enter it, and scarcely the very fire itself, in which it consumes but slowly, as seeming to partake of a ferruginous and metallin shining nature, proper for sundry robust uses. It is doubtless of all timber hitherto known, the most universally useful and strong. (i.52)

Although it is mainly utilitarian in its purposes, Sylva also presents a philosophical and aesthetic justification for the reforestation of Britain, particularly in its fourth and final book, entitled Dendrologia: An Historical Account of the Sacredness and Use of Standing Groves, which first appeared in the second edition of 1670 and was greatly expanded in the subsequent editions of 1679 and 1706. In its final form, Dendrologia delves deeply into the ancient traditions of sacred groves, and it provides a classic argument for the creation of large open estates with park-like groves and tree-lined scenic vistas. Sylva provided a crucial impetus for the eighteenthcentury shift in British taste away from walled formal gardens and toward a more open style of landscape design that involved the extensive planting of trees. Almost singlehandedly, Evelyn's popular treatise created a vogue for forestry among the British gentry (Harrison 100). It advocated a new way of seeing forests: not merely as game-hunting preserves, or as sources of raw timber, but as having intangible aesthetic value and an intrinsic sacred character worthy of nurturance and preservation. In this way, Sylva marks the birth of forestry as a mode of imaginative dendrology, through which such diverse writers as Evelyn and Walter Scott sought to discover the vital roots of their own national identity.

Although he never traveled to Scotland, Evelyn was fascinated by what he had heard of its wild and remote character, and intrigued by the vanished abundance of the aboriginal Caedonian forest. In Sylva he describes these ancient forests:

[In ancient times] the whole island [of Britain] was almost but one vast forest, and wood so abounding, that what people might have had almost for carrying off the ground it grew on, is now grown so scarce, in those very places, as that fuel is sold by weight: . . . and here I might mention that vast Caledonian forest, heretofore in Scotland (whence the sea has its name), and the people Caledonians, having now not so much as a single tree to shew for it. Have we not then the greatest reason in the world to take all imaginable care for the preservation and improvement of this precious material? (ii.156)

Evelyn regards the almost total deforestation of Scotland as an ethical rationale for present-day conservation practices, calling for the "preservation and improvement" of existing woodlands. Moreover, in light of the extensive deforestation that has already occurred throughout the British Isles, especially in the wake of the English Civil War, Evelyn understands that the mere preservation of existing woodlands will not be sufficient. He advocates for the establishment of treenurseries, so that every British landowner may become a creator and nurturer of new trees, especially in "waste lands" that are otherwise unproductive. He writes:

We cannot pursue a better course [than to create a "semi-
nary"] for the propagation of timber-trees: For though it seem
but a trivial design that one should make a nursery of forest-
ers; yet it is not to be imagin'd, without the experience of it,
what prodigious numbers a very small spot of ground well cul-
tivated, and destin'd for this purpose, would be able to fur-
nish towards the sencling forth of yearly colonies into all the
naked quarters of a lordship, or demesnes; being with a pleas-
ant industry liberally distributed amongst the tenants, and dis-
pos'd of about the hedg-rows, and other waste, and
uncultivated places, for timber, shelter, fuel, and ornament,
to an incredible advantage. (i.12)

Evelyn here advocates for the establishment of tree-nurseries, not only for their practical value, but also for their symbolic significance, since by this means the landowner can become a generative force within and upon the landscape, nurturing barren lands into a state of fruitfulness. Through the establishment of nurseries or "seminaries," the landowner can replenish his "naked quarters" with an abundance of trees for purposes both economic and aesthetic.

Evelyn is keenly interested in Scotland as a possible source of new, hardy varieties of trees that may prove eminently useful in the re-establishment of English forests. He observes:

In the Scottish Highlands are trees of wonderful altitude... which grow upon places so unaccessible, and far from the sea, that (as one says) they seem to be planted by God on purpose for nurseries of seed, and monitors to our industry, reserved with other blessings, to be discover'd in our days amongst the new-invented improvements of husbandiy, not known to our southern people of this nation. Did we consider the pains they take to bring [such trees] out of the Alps, we should less stick at the difficulty of transporting them from the utmost parts of Scotland. (i.222)

For Evelyn, the unexplored regions of the Scottish Highlands may hold yet-undiscovered species of trees that may prove of great value in the re-establishment of English woodlands, perhaps in large measure due to their hardiness, remoteness, and sheer wildness of character. His interest in such matters is not by any means restricted the Scottish Highlands; he advocates for the introduction of useful "exotics" wherever they may be found, especially in America:

One thing more there is, which (for the use and benefit which these and the like exotics afford us) I would take hold of, as upon all occasions I do in this work: Namely, to encourage all imaginary industry of such as travel foreign countries, and especially gentlemen who have concerns in our 
American plantations, to promote the culture of such plants and trees (especially timber) as may yet add to those we find already agreeable to our climat in England. (i.218)

Among such "exotic" species, Evelyn is especially streng in his advocacy for the larch, a tree species indigenous to Europe but not yet well-known or widely planted in England. Evelyn describes the many useful properties of the larch:

That [the larch] flourishes with us, a tree of good stature (not long since to be seen about Chelmsford in Essex) sufficiently reproaches our not cultivating so useful a material for many purposes, where lasting and substantial timber is required: For we read of beams of no less than 120 foot in length, made out of this goodly tree, which is of so strange a composition, that 'twill hardly burn. . . . The lurix [larch] bears polishing excellently well, and the turners abroad much desire it. . . It also makes everlasting spouts, pent-houses, and featheridge,' which needs neither pitch or painting to preserve them; and so excellent pales, posts, rails, pedaments and props for vines, \&c. to which add the palats on which our painters separate and blend their colours, and were ... the tables on which the great Raphael, and most famous artists of the last age, eterniz'd their skill. (i.251-253)

Once again, Evelyn emphasizes not only the humble utilitarian purposes to which this kind of wood may be put, but also its more refined aesthetic properties, associating the larch with both the "palats" (palettes) and "table" (painted surface) of the great Italian Renaissance painter Raphael, whose works Evelyn had frequently encountered during his sojourn in Italy (1644-46).

Evelyn's Sylva proved to be one of the most widely influential works ever published in the field of forestry. Sylva appeared in four editions during Evelyn's lifetime, and seven more editions were published posthumously, including five ecited by the Scottish physician Alexander Hunter (17291809): 1776, 1786, 1801, 1812, and 1825 . The 1812 edition of Sylva received an extended and glowing review in the Qslarterly Review for March 1813. The author of this review (axcording to the Quarterly Review Archive), Thomas Dunham Whitaker (1759-1821), was an English clergyman and scientist well-qualified to evaluate the enduring contribution that Evelyn's Sylva had made to the practice of forestry in Britain. In this Quarterly Review article, Whitaker declares:

The republication of the Sylva opened the eyes of land owners by teaching them that the seeds of trees would grow in private seminaries, that there was no mystery in managing a nursery; and that a plant of six inches and one of as many feet, placed in equal circumstances, side by side, would, in seven years, almost invert their relative heights.
In this national and patriotic work [of reforestation], however, the great Scottish nobility took and have maintained the precedence. Nothing in South Britain equals the extent and magnificence of those artificial forests which these lords of whole provinces have spread over their wild domains. (51)

Whitaker describes the influence of Evelyn's work upon the practice of forestry throughout the British Isles, and he is especially emphatic about its influence in Scotland. Nowhere else has Evelyn's work had such a dramatic impact, especially through the planting of "artificial forests" by members of the "Scottish nobility" whose estates extend to "whole provinces." Whitaker is particularly enthusiastic about the introduction into Scotland of larch plantations, which "formed a new epoch in the history of planting." He affirms that the larch "is an acquisition to this island almost without a parallel" (51).

A few years later, in a review of Evelyn's Memoirs (April, 1818), the Quarterly Review once again praises his influence on British forestry. The author of this review was the poet Robert Southey, and he characterizes Evelyn's accomplishment in the most laudatory terms:

To no person so well as Evelyn could the office have been assigned of remedying this evil [of deforestation] and averting the fatal consequence which must have inevitably have ensued to our naval power, and thereby to the strength, the welfare, the independence, and the life of England. He effected this great object by awakening the land-holders to a sense of their own and their country's interests. Charles II., who loved the navy, and like his brother would have made a better admiral than a king, twice thanked him personally for the work; he had the yet more gratifying reward of living to know that many millions of timber-trees had been propagated and planted at the instigation and by the sole direction of that book [Sylva], - one of the few books in the world which completely effected what it was designed to do. (47)

Such a glowing endorsement of John Evelyn's work by the Quarterly Review would certainly have come to the attention of Sir Walter Scott, who was closely engaged with this periodical as a founding investor (in 1809) and frequent contributor. Scott was keenly interested in the science of forestry, and his personal library included the 1801 edition of Sylva, inscribed with Scott's signature on the title page (Advocates Library Catalogue). Scott endeavored to carry into practice many of Evelyn's preferred methods of reforestation on his own estate, Abbotsford, as Susan Oliver has discussed (594). Scott's extensive practical knowledge of forestry is apparent in an article that he published (anonymously) in the Quarterly Review of October 1827. In this article, Scott describes himself as having "some knowledge of the subject, from sixteen years' undeviating attention to the raising young plantations of considerable extent, upon lands which may be, in general, termed waste or unimproved" (559). 
Although the nominal topic of this review article is The Forester's Guide and Profitable Planter by Robert Monteath, the most important influence upon Scott's understanding of forestry is none other than John Evelyn. Indeed, the influence of Evelyn's Sylva is evident throughout this article, especially in those places where Scott seeks to express the general values and principles that should guide the practice of reforestation in Scotland. For example, in replanting open areas with timber, Scott argues, a landowner should not adopt a patchy or piecemeal approach. Instead, he argues for an approach that considers the "natural boundaries" of an existing landscape:

A more liberal projector would have adopted a very different plan. He would have considered that although trees, the noblest production of the vegetable realm, are of a nature extremely hardy, and can grow where not even a turnip can be raised, they are yet sensible of, and grateful for, the kindness which they receive. In selecting the portions of waste land which he is about to plant, he would, therefore, extend his limits to what may be called the natural boundaries, carry them down to the glens on one side, sweep them around the foot of the hills on another, conduct them up the ravines on a third, giving them, as much as possible, the character of a natural wood, which can only be attained by keeping boundaries out of sight, and suggesting to the imagination that idea of extent which always arises when the limits of a wood are not visible. (567, emphasis added)

Scott's concept of "natural boundaries" foreshadows what we would nowadays call an ecosystem approach to wildland management. Such an approach acknowledges the interdependence of all living things within a complex, dynamic system. Moreover, Scott's advocacy for large-scale tree plantations is based not solely on economic factors, but also on aesthetic criteria, taking firmly into consideration the appearance of the forest within its topographic setting. Like Evelyn, Scott seeks to practice a forestry of imagination, one that immediately appeals to the aesthetic and spiritual dimensions of human consciousness at the same time that it remains grounded in more practical considerations of thrift, productivity, and conservation.

Scott follows in Evelyn's footsteps by advocating the establishment of tree-nurseries by individual landowners throughout Scotland:

The planter ... ought to be possessed of one nursery or more, as near to the ground designed to be planted, as can well be managed.... Where he proposes to plant upon a large scale, it is of the highest consequence that the young plants should stand for two or three seasons in a nursery of his own. . . . There is also this advantage, that by raising the trees from seed, the forester makes sure of getting his plants from the best trees - an article of considerable importance, especially in the fir tribes. (564-565)
Scott bases his argument in favor of local nurseries upon the idea that trees must be well-adapted to their local habitat, either by virtue of growing from indigenous seed, or at least as the result of becoming seasoned to local conditions by spending a few years in a nursery before being transplanted to the wild. By doing so, he implicitly acknowledges the importance of micro-climate, including such factors as sunlight, rainfall, temperature, wind, and soil quality, to the growth of young trees. Elsewhere in this article (596), Scott mentions the harmful effect of herbivores (mice and hares) on the survival of acorns sown in the wild, thereby providing another key rationale for the establishment of local nurseries. Here again, Scott anticipates our current understanding of best practices in the field of wildland restoration.

Scott likewise follows Evelyn in recommending oak and larch trees as the most desirable species for the establishment of new forests. His preference for oak is easily explained:

Our choice of the first [the oak] will scarce be disputed; it is the natural plant of the island, and grows alike on highland and lowland, luxuriating where the soil is rich, coming to perfection, in many cases, where it is but middling, and affording a very profitable copsewood where it is scanty and indifferent. (574)

Scott's advocacy for the larch is less easily explained, because such commentators as Wordsworth had previously deplored its uniform appearance on the landscape. Scott defends the larch tree from such criticism:

We cannot, indeed, vindicate this valuable tree [the larch], in so far as outward beauty is concerned: Wordsworth has condemned its formality at once, and its poverty of aspect. Planted in small patches, the tops of all the trees arising to the same height, and generally sloping in one direction from the prevailing wind, the larch-wood has, we must own, a mean and poor effect. ... But where the quantity of ground planted amounts to the character of a forest, the inequalities of the far-extended surface give to the larches a variety of outline which they do not possess when arranged in clumps and patches, and furnish that species of the sublime which all men must recognize in the prevalence of one tint of colouring in a great landscape. (574-575)

In defending the widespread monocultural planting of larch trees, Scott recurs to his argument concerning the importance of scale in the design of forest landscape. By avoiding the distribution of trees in awkward "clumps and patches," the landowner can accommodate the extent of his forest to the grand scale of the Scottish landscape, thereby creating an appearance that is truly sublime in its effect upon the beholder.

Although such a landscape solution might not work within the comparatively smaller scale of the English Lake District, Scott argues that it will prove highly effective within 
the grander scenic dimensions of Scotland. Such a site-specific solution is very much in harmony with an ecosystem approach to forestry, one that takes into account the topographic and bioregional factors that uniquely characterize a given location. It is also apparent that aesthetic factors such as sublimity very strongly affect the outcome of Scott's analysis, overshadowing more pragmatic social and economic considerations. He values the deciduous larch tree for its changing appearance in springtime, its dynamic appeal to the eye:

In spring, too, the larch boasts, in an unequalled degree, that early and tender shade of green which is so agreeable to the eye, and suggests to the imagination the first and brightest ideas of reviving nature. (575; emphasis added)

By ascribing inherent value to the seasonal appearance of the larch tree, rather than merely calculating its economic value, Scc.tt is truly practicing a forestry of imagination.

Such an aesthetic approach to the appreciation of landscape is likewise apparent in an article that Scott publist:ed in the Quarterly Review of March 1828, where he envisions the kind of wildlife habitat that most directly nourishes human awareness of "natural beauty":

But the character of abode which is required by these noble animals of the chase [i.e. stags] is precisely the same which, from its beautiful effects of light and shadow, from its lonely and sequestered character, from the variety and intricacy of its glades, from the numerous and delightful details which it affords on every point, makes the strongest and most pleasing impression on all who are alive to natural beauty. (311)

Once again avoiding a crude instrumentalism, Scott evokes those dynamic features of forest habitat that appeal most strongly to those observers who have learned to appreciate the changing beauty of the natural world. Indeed, these same subtle and elusive characteristics are those that have always appealed to the poetic sensibility:

The ancient English poets, Chaucer and Spenser in particular, never luxuriate more than when they get into a forest; by the accuracy with which they describe particular trees, and from their noticing the different characters of the different species, and the various effects of light and darkness upon the walks and glades of the forest, it is evident that they regarded woodland scenery not merely as associated with their favourite sports, but as having in itself beauties which they could appreciate. (311)

In short, although the forest is made up of individual trees, it is not trees in themselves that compose the most salient elements of the forest landscape. For Scott, the contrasting effect of various tree species, and the dynamic variation of light and darkness, constitute the inherent appeal of such a landscape.
Scott was certainly the single most important conduit by which a scientifically-based practice of forestry became intellectually available to the landowners and policy-makers of Scotland. His advocacy for a distinctively Scottish mode of forestry foreshadows the development of a conservationist ethic in the management of forests and wildlands throughout the English-speaking world. Scott adapted Evelyn's philosophical and aesthetic arguments from their original (English national) context to advocate for the widespread reforestation of Scotland. Economic impetus was not the central motivation for Scott's arboricultural viewpoint; indeed, Scott was instrumental in articulating cultural and aesthetic reasons for the carefully considered planting of areas designated as "waste land." In this way, Scott enabled the rediscovery of Scottish national identity through the recovery of a complex forest ecosystem, one that sought to provide rich habitat for rare birds and wandering minstrels. Within their distinctive national and historical contexts, Evelyn and Scott both have been instrumental to the adaptive process of cultural understanding and to the continuing development of the literary environmental imagination.

\section{NOTES}

I "Featheridge," that is, feather-edge, a fine edge produced by tapering a board or plank for use as a shingle, clapboard, or strake.

\section{WORKS CITED}

Advocates Library Catalogue. http://voyager.advocates.org. uk (accessed 18 February 2013); Darley, Gillian. John Evelyn: Living for Ingenuity. Yale UP, 2006; Evelyn, John. Sylva, or A Discourse of Forest-Trees and the Propagation of Timber in His Majesty's Dominions. 4th ed. 2 vols. London, 1706. Republished Doubleday \& Co., 1908, ed. John Nesbit.; Harrison, Robert Pogue. Forests: The Shadow of Civilization. U of Chicago P, 1992; Oliver, Susan. "Planting the Nation's 'Waste Lands': Walter Scott, Forestry and the Cultivation of Scotland's Wilderness." Literature Compass 6/3 (2009): 585-598; Quarterly Review Archive, ed. Jonathan Cutmore. http://romantic.arhu. umd.edu/reference/qr (accessed 1 January 2013); Quarterly Review, vol. 9, no. 17 (March 1813), [Thomas Dunham Whitaker] on John Evelyn, Sylva, or a Discourse of Forest Trees and the Propagation of Timber in his Majesty's Dominions, 45-57; Quarterly Review, vol. 19, no. 37 (April 1818), [Robert Southey] on Memoirs, illustrative of the Life and Writings of John Evelyn, 1-54; Quarterly Review, vol. 36, no. 72 (October 1827), [Walter Scott] on Robert Monteath, The Forester's Guide and Profitable Planter, 558-600. Quarterly Review, vol. 37, no. 74 (March 1828), [Walter Scott] on Henry Stueart, The Planter's Guide, 303-344. 